\title{
G2/Mitotic-Specific Cyclin-B3
}

National Cancer Institute

\section{Source}

National Cancer Institute. G2/Mitotic-Specific Cyclin-B3. NCI Thesaurus. Code C139675.

G2/mitotic-specific cyclin-B3 (1395 aa, 158 kDa) is encoded by the human CCNB3 gene.

This protein plays a role in cell cycle regulation. 